\title{
Realism, Science, and \\ Pragmatism
}

\section{Edited by Kenneth R. Westphal}

\section{ROUTLEDGE STUDIES IN CONTEMPORARY PHILOSOPHY}

Realism, Science, and Pragmatism

Edited by Kenneth R. Westiphal 
First published 2014

by Routledge

711 Third Avenue, New York, NY 10017

and by Routledge

2 Park Square, Milton Park, Abingdon, Oxon OX14 4RN

Routledge is an imprint of the Taylor \& Francis Group, an informa business

(C) 2014 Taylor \& Francis

The right of the editor to be identified as the author of the editorial material, and of the authors for their individual chapters, has been asserted in accordance with sections 77 and 78 of the Copyright, Designs and Patents Act 1988.

All rights reserved. No part of this book may be reprinted or reproduced or utilized in any form or by any electronic, mechanical, or other means, now known or hereafter invented, including photocopying and recording, or in any information storage or retrieval system, without permission in writing from the publishers.

Trademark Notice: Product or corporate names may be trademarks or registered trademarks, and are used only for identification and explanation without intent to infringe.

\section{Library of Congress Cataloging-in-Publication Data}

Realism, science, and pragmatism / edited by Kenneth R. Westphal. pages $\mathrm{cm}$. - (Routledge studies in contemporary philosophy ; 58)

Includes bibliographical references and index.

1. Realism. 2. Science-Philosophy. 3. Pragmatism. I. Westphal, Kenneth R., editor of compilation.

B835.R3265 2014

$149^{\prime} .2-\mathrm{dc} 23$

2013041610

ISBN: 978-1-138-01882-2 (hbk)

ISBN: 978-1-315-77951-5 (ebk)

Typeset in Sabon

by Apex CoVantage, LLC 


\section{Realism, Science, and Pragmatism}

"This is a first-rate collection of essays on the general issue of realism, on the relation of realism to contemporary philosophy of science and epistemology, and on the challenge that has been made to traditional realism by classical pragmatism and neo-pragmatism. The contributors are among the leading scholars in the field, and their essays advance the debates in ways that will provoke response and further inquiry. Anyone interested in the topic of realism, its history and current controversies, will benefit from paying the close attention that these essays deserve."

-John Ryder, American University of Ras al Khaimah, United Arab Emirates

This collection of original essays aims to reinvigorate the debate surrounding philosophical realism in relation to philosophy of science, pragmatism, epistemology, and theory of perception. Questions concerning realism are as current and as ancient as philosophy itself; this volume explores relations between different positions designated as 'realism' by examining specific cases in point, drawn from a broad range of systematic problems and historical views, from ancient Greek philosophy through the present. The first section examines the context of the project; contributions systematically engage the historical background of philosophical realism, re-examining key works of Aristotle, Descartes, Quine, and others. The following two sections epitomize the central tension within current debates: scientific realism and pragmatism. These contributions address contemporary questions of scientific realism and the reality of the objects of science, and consider whether, how or the extent to which realism and pragmatism are compatible. With an editorial introduction by Kenneth $\mathrm{R}$. Westphal, these fourteen original essays provide wide-ranging, salient insights into the status of realism today.

Kenneth R. Westphal is Professorial Fellow in the School of Philosophy at the University of East Anglia, UK 


\section{Realism, Science, and Pragmatism}

The project is an important one - the reconciliation of realism and pragmatism .... The book is attractive for ... the intellectual strength of the contributions [and its] ... organiziation [which] does justice to the wide range of related issues. The idea of considering the topic of realism from various points of view is original. $[\mathrm{It}]$... is not easy to find ... a volume ... which ... combines the various discussions.

This ... is a strong set of original essays on a number of significant aspects of the ongoing debate concerning philosophical realism. [Most] ... contributors are prominent figures [who] ... bring ... considerable experience and knowledge to bear in these essays to good effect. The editor [has] ... done a first-rate job of selecting and organizing the essays. Most of the authors are from Scandinavian universities, and ... build on the strong philosophical tradition that has built up around Helsinki.

The first section provides a general and high altitude overview of the topic, and then several essays that review highlights of the historical background. The rest of the volume is cleverly divided into two ... themes that more than any other capture the tension in the current debates: scientific realism and pragmatism, thus ... assuring ... a comprehensive study of the question in its current incarnations.

... the book ... has the strength of being pluralist in the breadth of its essays. ... These are interesting and provocative essays, and they should generate further discussion and debate. ... Any reader who goes through these essays carefully will have a good command of the topic generally and of the cutting edge discussions and debates. One cannot ask for more ... from a single volume.

... I [anticipate] ... the book being discussed in any Ph.D. program in which contemporary analytic and/or pragmatist philosophy is being studied. The book would be a valuable source in many kinds of courses in philosophy. ... Across Europe, especially in Scandinavia and countries in Central Europe, in Turkey, to some extent in Russia, and well beyond, there is growing interest in philosophy in these styles and dealing with these issues. It will be wise to market the book as much as possible around the world. 


\section{Contents}

Introduction

KENNETH R. WESTPHAL

1 What Is Real(ism)?

2 Aristotle's Direct Realism and Some Later Developments MIKA PERÄLÄ

3 Late Mediaeval Realisms: Key Arguments Supporting Non-semantic Universality

LAURENT CESALLI

4 Descartes on the Formal Reality, Objective Reality, and Material Falsity of Ideas: Realism through Constructivism? DERMOT MORAN

5 Quine's Conception of Objects: Beyond Realism and Anti-realism ANTTI KESKINEN

6 Did Sherlock Holmes Inhale Pipe Smoke through a Hole in His Forehead?

PETER SWIRSKI

\section{PART II}

Scientific Realism

7 Realism: Metaphysical, Scientific, and Semantic 
viii Contents

8 Scientific Realism: Independence, Causation, and Abduction ILKKA NIINILUOTO

9 Cognitive Semantics and Newton's Rule 4 of Experimental Philosophy: Scientific Realism without Empiricism KENNETH R. WESTPHAL

10 Naturalism without Metaphysics JONATHAN KNOWLES

\section{PART III}

Pragmatism and Realism

11 Majesty of Truth and the Moral Sentiment: Emerson's and Peirce's Ethico-Ontological Realism

HEIKKI A. KOVALAINEN AND DOUGLAS R. ANDERSON

12 Concepts and the Real in C. I. Lewis' Epistemology LAURI JÄRVILEHTO

13 Pragmatic Realism

SAMI PIHLSTRÖM

14 McDowell's Pragmatist Anti-anti-realism EIRIK JULIUS RISBERG

Contributors 


\section{Introduction}

\section{Kenneth R. Westphal}

Issues about realism are as current and as ancient as philosophy itself. Plato in the Theatetus comments on the long-standing battle between philosophical giants and gods about whether, in addition to the physical objects and events we perceive, there are also non-physical, and hence non-perceptible forms or ideas of kinds or characteristics, variously instantiated in physical particulars, but which exist independently both of their instances and of what we may happen to say, think, believe, or know about them. In philosophical usage, the term 'realism' is both basic and polysemic. For example, one can hold realismin contrast to idealism, irrealism, or agnosticism-if one holds that material objects exist and have various characteristics regardless of what we may say, think, believe, or know about them. One can be a direct realist in the theory of perception by holding that perception is direct awareness of external objects, a moral realist if one believes that there are objective moral values, a scientific realist if one holds that scientific knowledge is about theory-independent phenomena and that such knowledge is possible even about unobservable entities, or a modal realist if one believes that possible worlds are as real as the actual world. In ontology, realism indicates that one grants-in ways which vary from case to case-extra-mental existence to certain kinds of entities, processes, or structures and at least some of their features, such as physical objects, universals, relations, structures, or propositions. Realism about particular objects and about their features or relations became problematic in Twentieth Century philosophy when it became generally recognized that we cannot, as it were, set aside our concepts, theories, beliefs, or, in general, our language to inspect the facts themselves and on that basis assess our beliefs, statements, or theories about them. Realism has remained fraught since.

The fourteen original essays presented here explore the relations that different positions designated as 'realism' may have to each other by examining specific cases in point, drawn from a broad range of systematic problems and historical views from Ancient Greek philosophy up to the present day. Individually and taken together, these essays show how much can be gained by examining issues about realism both systematically and historically. The essays form three groups, Part I: Realism Contextualized, Part II: Scientific Realism, and Part III: Pragmatism and Realism. 


\section{Kenneth R. Westphal}

Part I contextualizes issues about realism regarding both physical particulars and universals by critically re-examining several major historical and systematic positions on these topics. A hallmark of pragmatism is that both the understanding and the assessment of current views, and the development of improved views, benefit, often centrally, by re-assessing prior views on the same or related issues, whether these prior views be familiar, neglected, under appreciated, or misunderstood. Accordingly Part I attempts neither a historical nor a systematic review of issues about realism; excellent surveys are available elsewhere. Instead, its six chapters re-investigate key historical and systematic issues where new and unexpected insights can be discovered-and discoveries there are in these chapters, which plumb philosophical depths in Ancient, Mediaeval, Modern, and Contemporary philosophy.

The issues are launched, officially yet non-technically, by Jaakko Hintikka in "What Is Real(ism)?" (Chapter 1). Hintikka articulates what is involved in claiming realism about any domain or issue or particular(s), in part by arguing that the use of possible world semantics requires a richer domain of discourse than is provided by any such semantics tailored to any one domain and its attendant possible-worlds model. To use such a logic we must be able to identify individuals across such domains and models, in order to identify any actual individuals within possible worlds, and to identify their merely possible, non-actual existence in some possible worlds, including that possible world which is our actual world. Accordingly, "actuality and existence do not go together," and epistemic logic requires a richer domain of discourse than that of Frege-Russell first-order quantification logic and the possible-worlds semantics built upon it. We need not only the 'is' of identity, the 'is' of predication, and the 'is' of instantiation, but also the 'is' of identifiability, as was implicitly recognized in Aristotle's logic and metaphysics. Epistemic logic requires possible objects as well as actual ones, and epistemic logic is required to use first-order quantification theory and possible-worlds semantics in any actual domain of inquiry.

In “Aristotle's Direct Realism and Some Later Developments" (Chapter 2), Mika Perälä elucidates Aristotle's direct theory of perception within Aristotle's general explanatory project. Aristotle's formal cause is specified in terms of the relevant efficient cause, the activity of which occurs in the activity of the patient. This model implies that, in perception, seeing, e.g., a white object is the type of perception it is because it is caused by a white object, where the object's white color exercises its power of being perceived in the sense of vision as someone's seeing that white of that object. That object's white color is the term to which the activity of the perceiver's sense, as the patient of the object's color's activity, is relative. This analysis enables Aristotle to solve problems in the Megarean and Protagorean anti-realist accounts of perception. Aristotle's view thus contrasts in important regards to those of, e.g., Aquinas and Scotus. Perälä examines two important contrasts. First, he argues that Aristotle, unlike Aquinas-and many of his successors even today-did not resort to the concepts of intentional being and 
likeness (and their cognates such as representation) to explain why a perception is about its proper object. Second, he points out that Aristotle, unlike Scotus, did not allow that a mental act could be directed at its object even when the object is not the efficient cause of that act (for example, when God or Devil induces such an act in us). Accordingly, Aristotle provides a cogent direct realist theory of perception.

Laurent Cesalli begins his examination of "Key Arguments Supporting Non-semantic Universality" in "Late Mediaeval Realisms" (to invert the sub-title and title of Chapter 3) by noting the highly favorable reception of Scotus's realism about universals by both C. S. Peirce and David Armstrong. Cesalli then critically examines key arguments for the real existence of universals developed by Aquinas, Scotus, Burley, Ockham, Buridan, Richard Brinkley, Nicolas of Autrécourt, Francesco da Prato, John Wyclif, and Dietrich of Freiberg, who argue that (i) semantic universality depends upon the existence of metaphysical universals, or that (ii) scientific knowledge requires metaphysical universals if it is not to be reduced to psychology or linguistics, or that (iii) essences of things exist objectively, no less than do their matter and forms. They analyze relations between universals and particulars in several ways: in terms of a merely formal distinction, mereology, concomitance, partial identity, real identity, or platonic-atomism. Cesalli further elucidates their views by critical comparison with modern forms of realism developed by Bergmann, Armstrong, and Cocchiarella.

In "Descartes on the Formal Reality, Objective Reality, and Material Falsity of Ideas: Realism through Constructivism?" (Chapter 4), Dermot Moran revisits Descartes' account of the formal and objective reality of ideas in order to ascertain more exactly Descartes' commitment to realism. For Descartes, as for the Scotist tradition in general, 'real' means something that can be a 'res': to be real is to be possible. The reality of some possible thing is expressed by its essence which is reflected in its 'objective reality'. Objective reality comes in degrees. Some 'real' entities also have actuality as a result of being caused. This is their 'formal reality'. For Descartes certain ideas (e.g., of God) have an objective reality so great that it can be accounted for only by those ideas also having formal reality. Other ideas have objective reality but fail to have a formal cause and may even mislead in presenting the kind of objective reality they possess. These are 'materially false' ideas. The received view is that Descartes' employment of these Scholastic notions is confused and that Antoine Arnauld in his Objections makes a number of valid criticisms of Descartes' account. Moran contends that Descartes' distinctions offer powerful insights into the intentionality of the mind and the manner in which the phenomenological character of our experiences can (or cannot) reliably lead us to grasp the nature of reality in itself. Descartes has a complex conception of intentional content that deserves more attention and credit than it has hitherto received.

In "Quine's Conception of Objects: Beyond Realism and Anti-realism" (Chapter 5), Antti Keskinen argues that the apparent tension between 


\section{Kenneth R. Westphal}

Quine's scientific realism and his epistemological conception of objects as theoretical posits is not resolved by appeal to Quine's naturalism, but instead by the genuinely reciprocal containment between science and epistemology. Quine's scientific realism and his epistemological conception of objects as posits are consistent because the notion of reality is itself always part of a theory; otherwise it is meaningless. The appearance of a tension between those two aspects of Quine's view arises only if it is assumed that objects can be real in some sense other than as posits of a theory included within our best current science. Quine disallows any metaphysical realism that has primacy over epistemology; hence his scientific realism is consistent with his epistemological view of objects as theory-dependent posits. Yet this conception of objects does not entail that the objects talked about in our best current science are less than real, in any admissible, theory-external sense of "real." However, Quine's view further implies that, although de re attitude ascriptions have sense, they are rarely true because the conditions necessary for their truthful ascription are rarely satisfied. Though no reductio, this implication of Quine's view is highly counter-intuitive.

The answer to Peter Swirski's titular question is no mystery: "Did Sherlock Holmes Inhale Pipe Smoke through a Hole in His Forehead?" (Chapter 6). The question is how we know that Holmes did no such thing, despite his being fictional, and why such knowledge matters. Swirski argues that such knowledge is not based simply upon the text, nor upon possible worlds implicated by the text or the author, not even when guided by a Reality Principle, a Mutual (Shared) Belief Principle, or by the fictional persona of the narrator. None of these proposals properly specify the relevant background beliefs or information required to understand literary texts. Recognizing what is relevant, Swirski argues, requires the reader's reflexive recognition of the real author's successfully executed reflexive intentions relevant to a given fiction, facilitated in part by our recognition of an author's use (or abuse) of genre conventions, and by our quintessentially human, natural capacities to understand one another's intentions and acts of directing joint attention. Our understanding of real intentions is required for comprehending one another, and for comprehending fictional truths.

Our reflections on realism began with quantification logic, according to which to be is to be the value of a bound variable, to argue that our understanding of possibility and of possible existence is required to use possible world models of any domain to understand actual features of actual objects or events, thus renewing our appreciation of Aristotle's insights into the 'is' of identification. The systematic and historical trajectory thus launched carries through the essays of Part I to conclude that our understanding of fictional truths requires our understanding of actual intentions and acts of joint attention, without which we could not communicate, and indeed could not be human. Part I thus provides the systematic and historical context of issues about the reality of objects, events, their characteristics, and their relations, within which Parts II and III examine these issues in greater detail. 
Part II considers a specific domain of these issues: scientific realism; Part III considers a distinctive approach to these issues: pragmatism.

Part II opens with Panu Raatikainen's "Realism: Metaphysical, Scientific, and Semantic" (Chapter 7). Raatikainen distinguishes and interrelates three influential forms of realism: realism about the external world, construed as a metaphysical doctrine; scientific realism about non-observable entities postulated in science; and semantic realism as defined by Dummett. He first contrasts metaphysical realism about everyday physical objects with idealism and phenomenalism, reviews several potent arguments against these latter views, and argues briefly by induction in support of realism about physical objects. Scientific realism-the idea that natural sciences discover and explain genuine features of natural phenomena-may be commonsense, and may be regarded as the paragon of empirical knowledge, though it has been widely out of philosophical favor, not only since Kuhn's Structure of Scientific Revolutions (1962), but throughout the history of empiricism, from Hume to the Logical Positivists, Logical Empiricists and today's Constructive Empiricists. Raatikainen distinguishes three forms of scientific realism: (i) scientific theories and their existence postulates should be taken literally; (ii) the existence of unobservable entities posited by our most successful scientific theories is justified scientifically; and (iii) our best current scientific theories are at least approximately true. Raatikainen argues that only some form of scientific realism can make proper sense of certain episodes in the history of science. He then considers Dummett's influential formulation of semantic issues about realism. Dummett argued that in some cases, the fundamental issue is not about the existence of entities, but rather about whether statements of some specified class (such as mathematics) have an objective truth value, independently of our means of knowing it. Dummett famously argued against such semantic realism and in favor of anti-realism. Raatikainen examines the relation of semantic realism to the metaphysical construal of realism, presents Dummett's main argument against semantic realism, and focuses on Dummett's key premise, that understanding the meaning of a declarative sentence involves knowing the conditions which would make that sentence true. Raatikainen argues against that key premise by appeal to semantic externalism.

Ilkka Niiniluoto's "Scientific Realism: Independence, Causation, and Abduction" (Chapter 8), examines three related criteria of realism within the sciences: mind-independence, causal power, and knowledge by abductive reasoning, by considering what a scientific realist should say about the reality of the past. He argues that realism about the past effectively rules out many anti-realist philosophical positions, such as subjective idealism, phenomenalism, solipsism, positivism, internal realism, social constructivism, and non- or anti-realist varieties of pragmatism. His analysis takes up the theme, announced by Hintikka's opening chapter, of object identification, in connection with Peirce's, Putnam's and with Pihlström's versions of pragmatism.

In "Cognitive Semantics and Newton's Rule 4 of Experimental Philosophy: Scientific Realism without Empiricism” (Chapter 9), Kenneth 


\section{Kenneth R. Westphal}

Westphal argues that Evans' analysis in "Identity and Predication" (1975) provides the basis for a powerful semantics of singular, specifically cognitive reference which directly and strongly supports Newton's Rule 4 of (experimental) Philosophy in ways which support Newton's realism about gravitational force. He first examines Newton's Rule 4 and its role in Newton's justification of realism about gravitational force and then summarizes Evans' account of predication and examines its implications for the semantics of singular cognitive reference. Westphal argues that this semantics of singular cognitive reference is embedded in and strongly supports Newton's Rule 4, and that it rules out Cartesian, infallibilist presumptions about empirical justification generally. He then argues that this semantics of singular cognitive reference reveals a key defect in Bas van Fraassen's main argument for his anti-realist "Constructive Empiricism," and also in many common objections to realism, both commonsense and scientific. More generally, Westphal argues, "realism" has appeared problematic to the extent that, in their focus upon the semantics of conceptual content or linguistic meaning, philosophers have neglected the further requirements for specifically cognitive reference.

In "Naturalism without Metaphysics" (Chapter 10), Jonathan Knowles argues-against wide-spread consensus to the contrary-that scientific naturalism, the thesis that natural science is our unique source of fundamental knowledge and explanation, does not require metaphysical realism, so that a scientific naturalist can reject metaphysics. Drawing on the work of Huw Price, Knowles argues against a naturalistic form of metaphysical realism that builds on a substantive notion of reference, and also argues (contra Devitt and Searle) that one cannot have a substantive realistic position without such a notion. Further, science itself does not militate for a naturalistic metaphysical realism. The correct alternative to realism, Knowles argues, is not Huw Price's "subject naturalism," which purports to explain scientifically the pluralism exhibited by language, including scientific language, by a global "expressivist" theory of content. Knowles argues that Price's approach leads to another, equally problematic kind of metaphysics, and its semantics lacks the scientific credentials claimed for it. The proper middle ground, Knowles contends, recognizes that semantic minimalism need not reduce truth to justification nor to warranted assertability, and that the systematic search for truth, which grapples with what is yet unknown, remains the prerogative of the sciences. These are the keys to a scientific naturalism without metaphysics.

Pragmatist and neo-pragmatist themes are sounded repeatedly in Parts II and III; they are examined in detail in Part III: Pragmatism and Realism. In "Majesty of Truth and the Moral Sentiment: Emerson's and Peirce's Ethico-Ontological Realism" (Chapter 11), Heikki Kovalainen and Douglas Anderson argue that, although they are often logically independent doctrines, realism about physical objects and realism about universals intersect in the religiously influenced interpretation and reception of Plato from the 
early church Fathers up to Romantics such as Samuel Taylor Coleridge, according to whom Christianity embodies universal truths, nonhuman in origin yet knowable to human reason by intellectual intuition-a faculty Kant famously denied. This Platonic, religiously inclined ontological realism enters American philosophy via Ralph Waldo Emerson. Emerson's notion of the moral sentiment is an intellectual faculty of intuiting universal truths—à la Coleridge—and a non-human real force operating in realityanticipating Peirce. Kovalainen and Anderson argue that both Emerson and Peirce advocate ethico-ontological realism. Understanding Peirce's theory of inquiry and his ontology requires recognizing their moral and theological aspects. More generally, they contend, understanding the issues of realism about particular objects, their features, and their relations requires grappling with the moral and theological dimensions of these issues.

In "Concepts and the Real in C. I. Lewis' Epistemology" (Chapter 12), Lauri Järvilehto argues that Lewis developed an aspectual realism that avoids relativism. According to Lewis, concepts guide our attention in what we experience. Concepts combine to form conceptual principles, which function as categorial laws by which we classify whatever we experience. If an experience does not conform to our conceptual expectations, we classify that experience as non-veridical. Consequently, our attributions of reality depend in part on the conceptual principles we employ. This seems to result in a very strong relativism: what is real depends upon the concepts and classifications we devise. This apparent relativism arises from a terminological ambiguity: Lewis uses the term 'real' both to designate that to which we attribute reality within our conceptual scheme, and to designate what there actually is, which we encounter, experience, and classify. The fact that a classification works for our purposes, and thus serves to attribute reality to some kinds of particulars, shows that what we so classify is, albeit aspectually, metaphysically real. Thus Lewis advocates perspectivalist or aspectualist realism rather than relativism. Indeed, the very logic of relativity, Lewis argues, undercuts relativism.

In "Pragmatic Realism” (Chapter 13), Sami Pihlström-himself a major exponent of this view-reassesses and further develops his pragmatic realism by re-examining the Kantian roots and character of pragmatic realism and the debates about realism in the classical pragmatism of Peirce, James, and Dewey, and by differentiating and defending his view by critically examining the views of three other contemporary pragmatic realists: Margolis, Westphal, and Vihalemm. Pihlström argues that sustained controversy about and tensions between realism and pragmatism are not a plague, but instead a strength of pragmatism and an important source of its continuing vitality. Pihlström argues that, in both its classical and in its contemporary forms, pragmatic realism is distinct, e.g., from both social constructivist and metaphysical realist accounts of the world and of our knowledge of it, both commonsense and scientific. Recognizing the distinctive virtues of pragmatic realism requires recognizing that whatever we justifiably regard 


\section{Kenneth R. Westphal}

as real must result from inquiry, and those results and the form(s) they take can be neither pre-determined nor presupposed. That is the cardinal mistake of many commonsense, scientific, and metaphysical forms of realism. Pihlström develops a pragmatic realism which combines a (naturalized) transcendental idealism with pragmatic realism and naturalism in a circular (though not viciously circular) structure: We transcendentally constitute the world through engaging in worldly (and entirely natural) practices, including practices of inquiry, which themselves are constituted through this same continuing process; there is no Archimedean fundamentum of our transcendental world-constitution.

In "McDowell's Pragmatist Anti-anti-realism” (Chapter 14), Eirik Julius Risberg re-examines the debate between Rorty, Davidson, McDowell, and now joining them, the 'New Pragmatists', about the character and status of objectivity in a philosophy cleansed of the dualism of conceptual scheme and empirical content. Rorty has long argued that any supposed answerability of our words to a world beyond the linguistic community is fundamentally misguided. The New Pragmatists contend instead that the notion of objectivity is not inimical to pragmatism. In particular, Ramberg argues, against Rorty, that Davidson's insistence upon the irreducibility of the intentional marks a post-ontological distinction between the intentional and the non-intentional, which provides for our intentional thought to be answerable to the non-intentional, in a way compatible with pragmatism. Rorty has accepted Ramberg's criticism, but still maintains that McDowell's view of the answerability of thought to the world is metaphysical and beyond the pale of pragmatism. Against Rorty, Risberg argues that Davidson's postontological distinction between the intentional and the non-intentional, and Rorty's accepting that distinction, suffice to show that McDowell's "anti-anti-realism" belongs within the pragmatist fold. Although McDowell and Davidson disagree about the boundary between the intentional "space of reasons" and the non-intentional "space of nature," McDowell's distinction is as post-ontological as Davidson's. Consequently, McDowell's view is tantamount to pragmatist anti-anti-realism.

Many of these essays originated from the conference, "Realism in Its Multiple Forms: A Case of Mere Homonymy or Identifiable Common Commitments?" (6-9 June, 2011), hosted by the Helsinki Collegium for Advanced Studies. It was sponsored jointly by the Helsinki Collegium for Advanced Studies; by the research project, "The Ethical Grounds of Metaphysics" (Universities of Helsinki and Jyväskylä), funded by the Academy of Finland; by the Nordic Pragmatism Network, funded by NordForsk; and by the Swiss National Science Foundation. All of the contributors, and I in particular, express our gratitude to these sponsors for their manifest confidence in, and concrete support of, our research.

Papers presented there have been substantially revised for the present volume, and several contributions have been specially written for it. 
Originally I had proposed to Sami Pihlström that we co-edit this volume. I have consulted him at every step, yet by happy coincidence I handled the editing: I had the time, whereas Sami was busy directing the Helsinki Collegium for Advanced Studies. More significantly, the contributors have all been wonderful collaborators; hence no problems arose which required extra brain-storming. I wish to thank each contributor for his fine contribution and exemplary cooperation; my special thanks are to Sami for his thoughts, advice, and assistance. I believe all the contributors join me in thanking Sami very warmly for having organized the very successful conference which launched this project, and in thanking the sponsors who made that conference possible, and hence this volume too. Last though not at all least, I wish to thank the Helsinki Collegium for Advanced Studies for its warm hospitality and ideal working conditions, where as a (former) member of its Academic Advisory Board I was allowed to spend the final quarter of 2011, when most of the editorial work on this volume was undertaken. The editorial and production staff at Routledge have been thoroughly professional, the very model of integrity in academic publishing, for which we are all very grateful indeed. 


\section{Contributors}

Douglas R. Anderson is Professor of Philosophy at Southern Illinois University at Carbondale. He is author and editor of several books and numerous essays dealing with issues in American philosophy and culture. He is former Editor-in-Chief of the Transactions of the Charles S. Peirce Society and of the Journal of Speculative Philosophy. Presently he edits a book series in American thought for Fordham University Press. His recent work includes Philosophy Americana (2006) and, with Carl Hausman, Conversations on Peirce (2012).

Laurent Cesalli, Chargé de rechrerche at the CNRS (UMR 8163, Savoirs, Textes, Langage, Université de Lille 3), was born in 1968 in Vevey, Switzerland. He studied philosophy and musicology in Fribourg (1988-93), survived training as a mountain guide (1994-97), and bicycled from Geneva to Beijing (1995-96). Since 1998 he has worked at the universities of Geneva (PhD in Mediaeval philosophy, supervised by Alain de Libera), Freiburg in Breisgau, Lausanne, Fribourg $(\mathrm{CH})$, and Cornell, NY. His field of research is semantics and ontology in mediaeval as well as in Austro-German philosophy. He is completing a monograph on Anton Marty's philosophy of language.

Jaakko Hintikka is Honorary Fellow in the Helsinki Collegium for Advanced Studies, and has received many international honors and awards. He was a Junior Fellow at Harvard (1956-59) and has held Professorships at the University of Helsinki, the Academy of Finland, Florida State University, and Boston University, and was affiliated with Stanford University (1965-82). His interests span philosophy of language, mathematical and philosophical logic, epistemology, philosophy of science, cognitive science, philosophy of mathematics, and history of philosophy, especially Aristotle, Descartes, Kant, Peirce, and Wittgenstein. He is the main architect of game-theoretical semantics and of the interrogative approach to inquiry, and one of the architects of distributive normal forms, possibleworlds semantics, tree methods, infinitely deep logics, and contemporary theory of inductive generalization. He has authored or co-authored over 


\section{Contributors}

30 books and monographs in nine languages. He has edited or co-edited 17 volumes and authored or co-authored over 300 scholarly papers, including five volumes of Selected Papers (1996-2003). The Philosophy of Jaakko Hintikka appears in the Library of Living Philosophers (2006, vol. 30).

Lauri Järvilehto, $\mathrm{PhD}$, is a researcher and trainer at Filosofian Akatemia, Helsinki, and a Post-doctoral Affiliate at the Aalto University Systems Analysis Laboratory. His current research on 'Intuitive Thinking and Decision Making' draws upon recent developments in the philosophy of mind, cognitive psychology and neuroscience, and also the epistemology and semantics of C.I. Lewis, whose conception of a priori knowledge was the topic of Järvilehto's doctoral dissertation. Järvilehto has lectured on theoretical and applied philosophy at many Finnish universities, and at universities in Great Britain, France, Germany, Sweden, Denmark, and Estonia.

Antti Keskinen is a Post-doctoral Researcher at the University of Tampere, where he earned his PhD in 2010 with his dissertation, Quine's Critique of Modal Logic and his Conception of Objects. He has interpreted Quine's rejection of de re modalities on the basis of Quine's view of objects as posits. Currently he is researching the role of social cognition (empathy) in Quinean epistemology and philosophy of language, and problems related to the ascription of de re propositional attitudes. Part of the research on his contribution to this volume was done as a Post-doctoral Researcher at the University of Uppsala.

Jonathan Knowles is Professor of Philosophy at the Norwegian University of Science and Technology in Trondheim, Norway. He studied at the universities of Oxford, Edinburgh, and London, gaining his $\mathrm{PhD}$ in 1995 with a thesis on the philosophy of cognitive science and linguistics. He has written Norms, Naturalism and Epistemology: The Case for Science Without Norms (Palgrave 2003) and edited (with Henrik Rydenfelt) Pragmatism, Science and Naturalism (2011). He has published papers on folk psychology and explanation, knowledge of grammar and linguistic competence, reductionism in psychology, naturalistic theories of norms, the nature of naturalism, and realism and naturalized epistemology. He sits on the board of the Nordic Pragmatism Network.

Heikki A. Kovalainen is a Philosophy Researcher at the University of Tampere, Finland. His work centers on the intersections of American and Continental thought, including classical authors (especially Emerson and Nietzsche) as well as contemporary thinkers (especially Cavell and Rorty), focusing on philosophies of life richer than Lebensphilosophie and phenomenology, and encompassing both life's vulgarity and its sublimity. His 
publications include the monographs Self as World-The New Emerson (2010), Emerson ja filosofia [Emerson and Philosophy] (2007), and the articles "Emersonian Moral Perfectionism: An Alternative Ethics-But in What Sense?" (2010) and "Emersonian Self-Culture and Individual Growth: The American Appropriation of Bildung” (2013).

Dermot Moran holds the Chair of Philosophy (Metaphysics \& Logic) at University College Dublin and is a Member of the Royal Irish Academy. A graduate of University College Dublin and Yale University, he has taught at Queen's University Belfast and Maynooth College, and held visiting professorships at Yale University, Connecticut College, Rice University, and Northwestern University. He has published widely on mediaeval philosophy (especially Christian Neoplatonism) and contemporary European philosophy (especially phenomenology). His books include The Philosophy of John Scotus Eringena (1989, 2004), Introduction to Phenomenology (2000), and Edmund Husserl: Founder of Phenomenology (2005). He is Founding Editor of The International Journal of Philosophical Studies.

Ilkka Niiniluoto is, since 1977, Professor of Theoretical Philosophy at the University of Helsinki, and former Chair of the Department of Philosophy (1983-88, 1992, 1995-2000). He is former Rector of the University of Helsinki (2003-2008) and former Chancellor of the University (2008-2013). He has published widely on philosophy of science, and especially scientific realism. His books include Is Science Progressive? (1984), Truthlikeness (1987), and Critical Scientific Realism (1999). He was Associate Editor of Synthese (1973-76), then Editor (1977-79), and a member of its editorial board (1980-2007). He is Editor-in-Chief of Acta Philosphica Fennica (since 1980), and President of the Philosophical Society of Finland.

Mika Perälä holds an Academy of Finland Postdoctoral Research Fellowship in the University of Helsinki. Previously he was Postdoctoral Researcher in the Philosophical Psychology, Morality and Politics Research Unit, University of Jyväskylä, Academy of Finland. His doctoral dissertation examined Aristotle's account of perceiving that we see and hear. After obtaining his doctorate in Helsinki (2010), he pursued postdoctoral studies at Oriel College, Oxford, 2010-2011. He is currently writing articles on Aristotle's theory of perception, and a monograph on Aristotle's account of memory.

Sami Pihlström is, since 2006, Professor of Practical Philosophy at the University of Jyväskylä and, since 2009, Director of the Helsinki Collegium for Advanced Studies. He has published widely on the problem of realism and related matters, including the pragmatist tradition. His recent books 
include Pragmatist Metaphysics: An Essay on the Ethical Grounds of Metaphysics (2009), and Transcendental Guilt: Reflections on Ethical Finitude (2011); he edited the Continuum Companion to Pragmatism (2011) and is an Executive Editors of SATS: North European Journal of Philosophy and is the Book Review Editor of the Transactions of the Charles S. Peirce Society.

Panu Raatikainen is Adjunct Professor of Theoretical Philosophy at the University of Helsinki and the University of Tampere. His research embraces logic, philosophy of mathematics, philosophy of language, philosophy of mind, philosophy of science, and the history of analytic philosophy. $\mathrm{He}$ has held Research Fellowships in the Academy of Finland and in the Helsinki Collegium for Advanced Studies, and visiting research posts at the University of St. Andrews, the University of London, and the City University of New York. He publishes in such journals as Analysis, Dialectica, Erkenntnis, Synthese, British Journal for the Philosophy of Science, and Journal of Symbolic Logic.

Eirik Julius Risberg is a doctoral student in philosophy at the University of Oslo, researching his dissertation on meaning and objectivity, including whether pragmatism can accommodate a notion of objectivity. Risberg holds an MA in philosophy from the University of Oslo and has been a visiting student at the University of California, Berkeley, and at the University of British Columbia, Vancouver. With support from Fullbright Foundation (USA) and the Norwegian Research Council, he spent the academic year 2011-12 as a visiting research student at the University of California, Berkeley.

Peter Swirski is Professor of American Literature and Culture at the University of Missouri-St. Louis, Honorary Professor in American Studies at Jinan University (China), Honorary Professor in American Studies at the South China University of Technology, and former Research Fellow in the Helsinki Collegium for Advanced Studies. His research ranges from American Literature and American Studies to interdisciplinary studies in literature, philosophy, and science. He is the foremost critic on the late writer and philosopher, Stanislaw Lem. His books include Between Literature and Science (2000), From Lowbrow to Nobrow (2005), Of Literature and Knowledge (2007), Literature, Analytically Speaking (2010), and was a National Book Award finalist for his Ars Americana, Ars Politica (2010).

Kenneth R. Westphal is Professorial Fellow in the School of Philosophy, University of East Anglia, Norwich. He has held Humboldt Research Fellowships at the universities of Heidelberg, Bielefeld, and Göttingen; and been Visiting Professor at Northwestern University and at 
the Martin-Luther-Universität Halle-Wittenberg. His research on the character and scope of rational justification in non-formal domains integrates systematic with historical, and analytic with hermeneutical philosophy. His books include Kant's Transcendental Proof of Realism (2004); he edited The Blackwell Guide to Hegel's Phenomenology of Spirit (2009). His recent articles include: "Kant's Critique of Pure Reason and Analytic Philosophy" (2010); "Self-Consciousness, AntiCartesianism \& Cognitive Semantics in Hegel's 1807 Phenomenology" (2011); “Norm Acquisition, Rational Judgment \& Moral Particularism" (2012); "Hume, Empiricism \& the Generality of Thought" (2013); "Natural Law, Social Contract \& Moral Objectivity: Rousseau's Natural Law Constructivism" (2013); and "Rational Justification \& Mutual Recognition in Substantive Domains” (2013). 


\section{Index}

(Note: close cognate terms are all listed under one main form, without mentioning the latter variants; e.g., 'actualism' also includes 'actualist'.)

abduction $143,147,149,159,166-7$, $169,225-7$

Absolute, the 222, cf. 231; absolute truth see truth, absolute; absolute $v$ s relative see relative

Achinstein, Peter 147

acquaintance, knowledge by, see knowledge, by acquaintance actualism 15,165

affairs, states of see states of affairs, also see fact(s)

affordance (perceptual) 214

Ahab (fictional character) 120

Aladdin 121

Alanen, Lilli 68, 82

Albert the Great (Albertus Magnus) 48, $77,238 \mathrm{n} 9$

Allison, Henry 268, 278, 279

Anderson, Carl 163

Anderson, Douglas 221, 255-6

anti-anti-realism 283-99

anti-realism 47, 93-6, 100, 105, $111,150,153-5,166,169$, 179, 214, 216, 284, 286, 291, 294-5, 298, also see empiricism, Constructive; empiricist 179, also see empiricism, Constructive; - , metaphysical 111 ; — , semantic 150-5, 169; also see bivalence, Dummett

anti-representationalism 214-5, 283-9 Aquinas, Thomas 22-3, 30-4, 39, 48-50, 52

Arabian Nights 116

Aristotle 17-19, 21-42, 49-50, 58, $61 \mathrm{n} 5,183$

arithmetic see mathematics
Armstrong, David 47, 48, 58-60, 141, 160, 280n41

Arnauld, Antoine 67-8, 70, 74, 76, 78 ascription of characteristics or properties see predication; of propositional attitude $94-5$, 106-12, 124, 196n13, 287-8, 297-9; _ , de dicto vs. de re 94, 106-7, 110-12; notional $v$ s. relational 108-12

assent 97-99, 102, 109, 196n9 also see dissent

assertability, warranted, see justification, warranted assertability

atomism 59

attention, joint, 129, 131-3 also see intentions

attitude, natural 70, 88, 143-4; ascription see ascription, of propositional attitude; - , non-egoistic see egoism; religious 221

Audi, Robert 257

author's intentions (authorial intentions) see intentions, author's

Avicenna 52

Ayer, Alfred Jules 141

Bacon, Roger 77

Baudelaire, Charles Pierre 117

Baudolino 129

belief, fixation of (Peirce) 223, 255, cf. 227

belief system 108, 110, 112, 123-5, $127,200, c f .88,213,239$ n17 
Bequerel, Henri 148

Bergmann, Gustav 56-9

Berkeley, George 85, 141, 142, 169, 174,229

Bhaskar, Roy 152, 165

biology 209, 214, 215, 275, 288, 272;

- , evolutionary 129,131 ,

141, 167-9, 212, 213, 234,

266, 275, also see paleontology;

primatology 130

bivalence, principle of 96, 150-3,

169; also see intuitionism, mathematical

Boghossian, Paul 204

Bohm-Aharonov experiment 20

Bohr, Niels 19

Bolzano, Bernard 73

Bonaparte, Napoleon 167

Borges, Jorge Luis 117, 119

Bouwsma, O. K. 184

Boyd, Richard 145, 147, 160, 167

Brandom, Robert 191, 200, 214-5, 284

Bratman, Michael 132

Brentano, Franz 57, 73, 83, 283

Brinkley, Richard 50

Bruner, Jerome 129

Buddhism 238n1

Buridan, John 48-9

Burley, Walter 47, 48, 50-3, 55-6, 59-60

\section{Canberra plan 204}

Carnap, Rudolf 144, 161, 183, 196n11

Cartwright, Nancy 146

category, categories 56, 102, 104,

160-3, 165, 206-7, 209, 213,

230, 243-9, 258-9, 272-3, also

see observation categorical, observation terms

causal agnosticism 179

causation, causality, cause 22-42,

$53,68-70,76-7,79,81-3$,

86-9, 103, 117, 128, 140, 142,

$146,148-9,159,160,163-9$,

173-9, 185, 190-3, 196n17,

206, 210-11, 216n6, 258, 268,

271-3, 283, 287, 290-1, 294,

297, 299

ceteris paribus clause 190-1, 196n17

Chisholm, Roderick 142

Chomsky, Noam 208, 212, 215 , $217 \mathrm{n} 15$

Circularity Accusation, the see justification, circularity
Clark, Herbert 129

classical pragmatism see pragmatism, classical

classification(s) see category

Cocchiarella, Nino 48, 58-9

cognitive science 212-15; also see

Theory of Mind (ToM)

Coleridge, Samuel Taylor 232

Comte, August 167

Conan Doyle, Arthur 119

conceptual scheme 144, 160, 243-9, 257, 263, 283, 285-7, 295, 298, 299n1; also see categories; belief system

confirmation holism see holism, confirmation

Constructive Empiricism see empiricism, Constructive

constructivism 14, 87, 93, 99-100, 104, 144, 150, 152, 161-2, 168 , 196n11, 226, 251-2, 255-6, 258, 260-2, 264-9, 274-7;

- , causal $v$ s. conceptual 67, $82,85,87-8,104,168-9,247-9$, 260-2, 265-9, 274-6; social see social constructivism content, of assertion 55, 99, 122, 164, 182, 189, 193, 214-15, 291-2, 295 ; - , cognitive 54, 107, 184-5; - conceptual 68, 87, 181-4; also see conceptual scheme; - empirical 94, 97, 98, 99, 101, 106, 109-12, 169, 216n9, 283, also see conceptual scheme; - experiential 68, $72,76,83,85,87-8,161$, 271,$296 ;-$, fictional 71 , $88,115-33,163 ;-$ - of idea see objective reality; —information 170 , also see Dretske; - - intensional 30-1, $59,67,69 ;-$, of judgment $55,68-9,71-6,83-7,120$, $128,167,182-4,228,244-6$, 259-60, 271; - , mental $55,184-5,279 \mathrm{n} 33$, also see ascription, of propositional attitude; - - , perceptual 22-42, $164 ;-$, phenomenological 68, $72,75,87 ;-$, representational 70, 74-5, 77, 79, 207 also see anti-representationalism; semantic $86,99,185,207,215$, also see content, conceptual; 
- - of sentence 99, 109; sensory $22-42,76,81,83$, 85 , also see - experiential, - , phenomenological, phenomenalism; _- of statement 214-15 also see reference, Thesis of Singular Cognitive; - - of thought 22-3, 54, 55, 70, 74-5, 77, $79,81,83,84,86,88-9,207$, 295 , also see ascription, of propositional attitude; objective reality

Convergent Realism see realism, Convergent

Copernicus, Nicholas 187

Coppola, Francis Ford 119, 122, 123

Corleone, Don (fictional character) 119,122

Corleone, Michael (fictional character) 123

Crawford, Sean 108, 110

critical scientific realism see scientific realism, Critical

Crusoe, Robinson (fictional character) 128

culture $104,115,128-31,159,160$, $163,165,168,170,231,233-4$, 261, 265, 287

Curie, Marie 148

Curie, Pierre 148

Davidson, Donald 195n3, 283-92, 296-9

Davies, David 128

denoting see reference

dependence see independence

Descartes, René 41, 42, 67-89, 187

description, knowledge by, see knowledge, by description descriptivism 144

Devitt, Michael 96-7, 100, 105, 111, $146,151,155,202,205-7$, $216 \mathrm{n} 13$

Dewey, John 164, 169, 222, 230, 251, 253, 254, 256, 259-62, 266, 268, 274, 277n9, 295

Diamond, Cora 234

dictum 61n6, 163, 228, 285

Dietrich of Freiberg 56-7

Ding an sich see things-in-themselves

Disch, Thomas M. 124

disjunctivism 41

disputed class (Dummett) 150-1, 153 dissent 48, 97, 99, 102, 109

distinction, de re vs. de dicto 107, also see ascription, of propositional attitude; - , formal 47, 54, 59, 60n $3,75,78 ;-$, among relatives (relations) 23, 27, $31,40-2 ;-$, relational $v s$. notional $113 \mathrm{n} 15$

domains, formal vs. non-formal (substantive) 183

Donnellan, Keith 182

dream 41, 163, 235, 243, 247-8

Dretske, Frederick 184

Duhem-Quine Thesis, the, 155

Dummett, Michael 96, 150-5, 166, 169, 286, 292-5

Dupin, Auguste C. (fictional character) 117

Dupré, John 208

dynamic, dynamics $161,254-5$ also see Newton, Isaac

Eco, Umberto 115, 121, 129

Edison, Thomas 148

egoism 221, 225, 226, 231, cf. 227

Einstein, Albert 144, 165, 174

Emerson, Ralph Waldo 221-37

empirical adequacy 177, 178, 188-93, $196 n 15$

empirical content, see content, empirical

empiricism 41, 100, 103-4, 110, 167, 178-9, 186, 259, 262, 287 ; — - concept or meaning $161 ;-$ Constructive (van Fraassen) 173, 184, 188-95; —_ radical 143, 154, 239n17; - , reductive $144 ;$ enactivism 214 enuntiabile $61 \mathrm{n} 6$ epistemic, epistemology 16-19, 31, $50,54,59,67,78,84,93-8$, 99-101, 103-6, 108-12, $118,143,152,154,159-60$, 162-5, 167, 169, 173-4, 181-8, 194-5, 236-7, 243-9, 252-3, 257-9, 264-71, 296, 298; naturalistic 58, 93-4, 101, 103, 105 , also see naturalism; utilities 154

epistemic conception of understanding see understanding, epistemic conception of 


\section{Index}

essence 38, 46, 49-54, 56, 59, 67,

69-70, 74, 82-4, 205, 229, 230,

259-60, 262; also see re

ethics, ethical (also moral) 140, 159,

160, 162, 213, 262, 267, 275,

289; — Christian 221-37;

—, of inquiry 221-37; —

moral sentiment 221, 224,

Euclid 18

231-7

Evans, Gareth 173, 180-2, 196n9

evidence, empirical or experimental

20, 95-7, 100, 103, 130, 148,

150, 163, 168-9, 174-6, 179,

186-9, 228, 288, 292; see also

observation

evolution, biological see biology,

evolutionary; —_, of beliefs or

ideas 226, 254, 299n4; — - of

reality 254,255

existence 1-20, 28, 51, 54, 58-9, 69-70, 93-5, 97, 99-103, 105,

$108,118,140,145-50,154-5$, 165-6, 174, 176, 179, 183, 200, 206, 209, 210, 223, 247, 252-3, 260, 296; —,$v s$. being 13, 15, 17, 162-3, 223-4, 247

explanation, Aristotle's model of 26 , 28-9; scientific — 143-4, 148-9, 159-60, 167, 174-9; also see science; boundary conditions 16; initial conditions 16, 177

exportation 108-9

expressivism 210-11

fact(s) 19, 55-60, 104, 117, 152, 162, 164, 185, 192-4, 200-10, 249, 257, 283, 286-99

faith (object of) 48, 221 also see God fallibilism see justification, fallible

falsity, formal vs. material 71-89

Feyerabend, Paul 144, 147

fictional truth see truth, fictional

Field, Hartry 152, 153

Fisch, Max 266

Flasch, Kurt 56

Flash Stockman (fictional character) 124-5

Fogelin, Robert J. 96-7, 100, 110-11

formalitas 47, 52, 68-9, 77-8

Francesco da Prato 53, 59, 60

Frege, Gottlob 13-17, 73, 152, 162, 206

fundamentum in re 50, 51
Galilei, Galileo 144, 195n7, 227

gavagai 129

General Theory of Relativity 174, 179

generalization by induction see induction

generals (Peirce) 223, 229, 236-7, 254-6, 266

Gettier, Edmund 194

Gibson, J. J. 214

Gibson, Roger F. 94, 100-1, 104

Giles of Rome 48

Gilson, Étienne 69, 77-8

Glymour, Clark 179

God, gods 16, 22-3, 39, 40, 49, 69-70, 73, 77-83, 86-7, 89, 141, 142, 169, 221, 223-4, 226-7, 229, 233, 235-7; God's-eye view 162, 257, 265, 269, 273, 276

Gödel, Kurt 15

Godfather, The 119, 122-3

Goodman, Nelson 169, 190, 191, 195n3, 258

Grice, Paul 131

Grubbe, Emil 148

Haack, Susan 95

Hacking, Ian 146, 165

haecceitas 52,164

Hale, Bob 152

hallucination 21, 38, 41, 42, 140, 246

Hannibal 121, 122

Hanson, Norwood Russell 147

Harper, William 173-86, 186, 187, 188, 192, 193, 196n12

Hausman, Carl 227, 254-6

Hector (fictional character) 120

Hegel, G.W.F. 214, 231, 261, 264-9

Hempel, Carl G. 190, 191, 195n3

history (discipline of historical inquiry)

170, 213; _ and philosophy of science (HPS) 173-80, 183, 187, 192-3; geohistory 168;

- , human 168, 234; ——,

natural 168, cf. 189, 192 also see past; natural _ of the intellect see intellect, natural history of; — of philosophy 17,18 , 251, 283 also see philosophy (periods); - of science 145-9, 163, 165-8, 173-80, 187

holism, of attitude ascription 288-90;

— , confirmation 99, 155;

—_, semantic 98, 101, 109;

_, social 132 
Hollywood 120

Holmes, Sherlock (fictional character)

$115,117,119,120,127$

Homer 18, 19

Horwich, Paul 152

Hume, David 69, 164-5, 174, 195n3, 238n10

Husserl, Edmund 67, 70, 73, 81, 83-5, $88,162,165$

Hutcheson, Francis 232

idealism 47, 140-4, 150-2, 161, 214, 251-6, 261-3, 275, 276;

- , conceptual 162; -

Mediaeval 46, 56-7; metaphysical 223, 236, 272;

- objective 162, 163, 169,

222, 223, 255; Refutation of

- (Kant) 271, (Moore) 161;

- , subjective $159,161,168$;

- transcendental 162, 232,

$251,253,259,263,265,266$,

270-5; - transcendental

pragmatic $263-9$

ideally justified see justification, ideal identification see 'is', of identification identity $24,46,99,100,101,105$,

$109,163,230$, also see 'is', of identification; - $\longrightarrow$, conditions (or criteria) 112n10, 163, 180-2, $274 ;$ — , partial 53, 59; and predication $173,180-2$;

- , temporal 141

illusion 25, 38, 41, 228, 243, 260-1

implication see logic

incommensurability 144

independence $v$ s. dependence 13 ,

96,161 , also see relative, $v$ s.

absolute; - - of language 57 ,

144, 200, 252-9, 284, 291;

- logical 14-15; _ _, of

mind or the mental 19, 21, 23,

$32,39,50,54,56,59-60,88$,

93, 140, 143, 146-8, 150, 152,

$155,159-68,200-2,205-7$,

213, 216n13, 224, 235, 243,

246-9, 264-7, 269, 272-3, 276,

$284,286,292 ;-1$, of practice

$252,261,263,274 ;$ -

theory $96-105,108,111,144$,

196n11, 200, 252

indeterminacy of translation see

translation, indeterminacy of induction, generalization 149, 166,

173-6, 195n 3

inductive argument for realism, see realism, inductive argument for infallibilism see justification, infallible inference to best explanation, see abduction

inquiry 276,$284 ;-$, interdisciplinary 274-5; _ , phenomenological 214 ; — , scientific 159-60, 162, 164, 168, 221-37, 252, 253-6, 259-62, 264, 274-5, also see method, scientific

instantiation 13-14, 40, 54, 58, 60, 84, 99, 207, 230, 236

instrumentalism 144, 145, 159, 164, $167,170,259-62$

intellect 32, 34, 39, 40, 50-7, 69, 71-2, $78,82,85-8,222,227-30$, 235 ; — - intuitive 232; understanding (Verstand) see understanding; - - natural history of, 222, 228, 230, cf. $169,234-5,264$

intentional, irreducibility of 283-99 intentionality (object-directedness) 22, 30-2, 41-2, 48, 56-9, 67, 69, 72-89, 124-7, 129, 182, also see ascription; attention, joint; content; - - 'we', 129, 130-3, also see attention, joint

intentions, author's $115,123,124$, $126-9$; — , reflexive 124,126 , $127,128,131-2$

intuition, forms of (Kant) 165, 232, $271 ;$ _ , intellectual see intellect, intuitive

intuitionism, ethical 232; mathematical 151, 169-70 also see bivalence; _ _ , modal 193

'is', of existence 13, 18 also see instantiation; - - of identity 13, 17 also see identity; —_, of identification 17-18, 19, cf. 142, 162-3, 168, 180-6, 194, 271-3, 274; - - of instantiation see instantiation; — of predication 13 also see predication; subsumption 13 , also see instantiation, predication

Iser, Wolfgang 116 


\section{Index}

Jackson, Frank 202, 204, 209

Jacobs, W. W. (William Wymark) 125-6 James, Henry 124

James, William 164, 222, 227, 229, 230, 231, 239n17, 251, 253, 256-9, 261, 262, 266-7, 268, 284-5

Je t'aime, je t'aime 128

joint attention see attention, joint justification, (vicious) circularity charge 142, 149, 154, 279n38; cognitive (epistemic) 149,175 , 182, 184-95, 195n 3,210 , 212, 283, 285; — , fallible $101,125,127,160,162,166$, 183, 186-93, 226, 227, 264-6, 273, 278n24, 279n35; ideal 152, 154, 164, 169, 224, 228, 237, 257; — infallible 173, 183, 186-93, 262; logical gaps 191-2; methodological 187; warranted assertability 169 , 299n3, cf. 227

Kant, Immanuel 16, 18, 56, 57, 144, $160,161-2,165,230,232$, 251-3, 255, 258-9, 263-72, $274,277,283,284$

Kaplan, David 108, 196n11

Kepler, Johannes 175-6, 195n7 knowing who/what 16-19, 54, 59, 108, 115ff, 181-4, 244, 247-9

knowledge, by acquaintance 19 ; by description 181-4; scientific $16,46,58,95,110$, 139-215 passim, 223, 235, 237, 253, 259-61, 274; — - of truth conditions see meaning, truthconditional theory of

Kruse, F. E. 222, 227

Kuhn, Thomas 144, 147, 154, 179

language, ideal 160; - natural 14, $46,97,132-3,143,153,165-6$, 180-1, 190, 196n9, 213, cf. 245; _-, ordinary see language, natural; - - philosophy of 184-5, 194-5, cf. 272, 290-1; —, pragmatics 188, 194-5; — , private 143,$293 ;$ truth-functional 191 language game (Wittgenstein) 160, 273 Latour, Bruno 144, 164
Leibniz, G. W. 15, 179

Lem, Stanislaw 118, 124, 127-9

Leplin, Jarrett 145-6, 167

Lewis, C. I. 141, 183, 191, 243-9

Lewis, David 119-127

Loar, Brian 108

logic, epistemic 13-20, also see knowing who/what; _erotetic 18-20; Law of Weakening 189-91; material implication, paradox of 191 ; modal 16-20, 27, 193, also see modality; possible worlds 16 , 122; quantificational 14-20, $95-6$; strict implication 190

Logical Empiricism 144, 146-7, 195n3 logical gap 42, 183, 187, 191-2

Logical Positivism 102, 141, 144, 159, 168, 195n3, 216n9, 287, cf. 243 Lotze, Hermann 73

Malbranche, Nicholas 142

Margolis, Joseph 251, 255-6, 263-70, 272,276

mathematics $15,18,39,68,79,84,95$, 140, 150-4, 163, 166, 169-70, 183, 193, 223, 233, 259-60, 292, 294; mereology 53, 58, 59; numbers 15, 22, 103, 104, 140 , also see intuitionism, mathematical

mature sciences see sciences, mature Maxwell, Grover 144, 147, 167 McCluskey (fictional character) 123 McDowell, John 200, 283-99

McGilvray, J. 215

M.D.: A Horror Story, The 124 meaning 13-14, 17-18, 47, 51, 59, $73,101,126,129,130-3,151$, 153-5, 180-4, 224, 244, 246-7, 258, 272, 286, 290, 292;

full-blooded $v s$. modest theory of 300n8; - , truth-conditional theory of 153-5, 292-5, 297-9; also see content, conceptual; pragmatic maxim; reference; semantic(s)

meaningful/meaningless(ness) 102 , 103, 104, 105, 106, 109, 111, 112n10, 143, 150, 152, 161, 169-70, 200-1, 258, 273, 276

Meinong, Alexis 57, 73

Menzies, Paul 202-4 
mereology see mathematics, mereology Merleau-Ponty, Maurice 214

Mersenne, Fr. Marin 67, 86 metaphor thesis (Dummett) 151 metaphysical anti-realism, see antirealism, metaphysical; —_, idealism, see idealism; ——, naturalism, see naturalism, metaphysical; __ , realism, see realism, metaphysical

metaphysics 14-20, 46-50, 57-9, 155, $162,163,169,174,200-15$ passim, 230, 232, 237, 243, 246-9, 254, 264, 266-74 passim, 283, 285-6, 289, 298;

—, Aristotelian 17-19, 33;

- Cartesian 69, 71, 73, 84;

—_, modal see logic, modal;

- Neo-Platonic 48, 54,

58-9, 226, 227, 230, 236;

- Platonic 15, 47, 49, 51, 60, 151-2, 237, 294;

pragmatist $162,221-300$ passim

method, scientific see explanation, scientific

Mill, John Stuart 141

Miller, Alexander 151, 153-4

mind and matter 222, 230

mind-independence see independence, of mind

mine disease (medical diagnosis) 148 minimal realism see realism, minimal Minimal Scientific Realism see realism, minimal scientific

miracle argument 147, 149

Misak, Cheryl 266, 284, 299n4 modality, causal 193-4; - logical 191, 193 also see logic; metaphysical 16, 19, 27, 79-80; also see re

"Monkey's Paw" (Jacobs) 125-6

moral sentiment see ethics, moral sentiment

Morris, Charles 194

Mother Teresa 115

Mrs. Dalloway 115

Murdoch, Iris 234, 236

Mutual Belief Principle 120-2, 125-6

Mutual Contextual Beliefs 127

natural attitude see attitude, natural;

—- history see history, natural;

— , kind 205, cf. 217n13, 288;

- natural; - , phenomena

174-5, 185, 187, 192-3; — , science see science

naturalism (philosophical) 93-112, 169, 200-80 passim; - Canberra plan (Jackson) 204;

- liberal 200, 201, 212;

- metaphysical 200-8, 209-15; - - minimal 200, $275-4 ;-$ - object $216 \mathrm{n} 7$; pragmatic 260-77, 279n38;

- reductive $205 ;-\square$, scientific 93, 95, 100, 200, 201, 207; - - subject (Price) 209-15; also see epistemology, naturalistic; science, natural nature, space of 285, 297, 298, 299 neo-pragmatism see pragmatism, neoneural stimulation 96-9,113n13 Newton, Isaac 122, 165, 173-80, 185-8, 191-4

Newtonian mechanics see Newton, Isaac

Nicolas of Autrécourt 51, 54, 59-60

Niiniluoto, Ilkka 261, 274

Noë, Alvin 214

nominalism 47-9, 57, 60, 161, 224, 229-30, 235-7, 262-3

non-intentional see intentional, irreducibility of; space of nature normative, norms $212,221,224-5$, 235-6, 252, 256, 275, 290-1, 295, 297-9, also see ethics numbers see mathematics

O'Regan, K. 214

object, abstract 13-14, cf. 32, 88, also see mathematics, numbers; - mathematical, see mathematics, numbers; - - physical 13-14, 93-106, 140-9, 151, 155, 160, 162, 164-9, 185, 254, 270-1, also see independence, of mind; realism; 161, 244, 247, 249, 257; object, possible 16-20, cf. 41, also see re; object, public 34-5, 97, cf. 106-12, also see attention, joint; observation, sentence; - , of a sign, immediate $v$ s. dynamic 161-2, 254, 255, cf. 180-2

objective reality (representational content of an idea) 42, 50, 54-6, 67-89 
objectivity 51, 164, 200-2, 206, 207, 224, 231, 255, 260-1, 266, 268-9, 283-99, also see independence, of mind; realism; _- ontological $v$ s. postontological 285-92, 297-9 observation, categorical (Quine) 95-101, 110; free $v$ s. focal forms $98,112 \mathrm{n} 5$; — 95-101; - - terms, vs.

theoretical terms see scientific terms, observational $v s$.

theoretical; ——, theory-laden see scientific observation, theory laden

occasion sentence 97

Ockham, William of, 47-50, 59;

Ockham's Razor 192-3

ontogeny 130

ontological commitment 93, 95, 96, 104, 105, 107, 165-6, cf. 192, 273, 291

ordinary language see language, natural Ortcutt, Bernard J. 107-10

"Oval Portrait, The" (Poe) 121-2

paleontology 168, cf. 141, 166, 168-9, 206

parsimony, explanatory see Ockham's Razor

particulars see object, physical

parts 46-7, 180-1; 53 ; — , formal $52-3$; integral $52 ;-$, metaphysical 49 , cf. 58 ; -

past $128,150,159,165-70,292$, also see history

Peirce, Charles Saunders 47-8, 143, 152, 160-7, 221-39, 251-6, 262-9, 272, 275

perceptual relativity see relativity, perceptual

perceptual similarity $97, c f .245,270-1$ also see observation sentence

Pessimistic Meta-Induction 149 phenomenalism 141-3, 150, 152, 153, 156n2, 159, 168

phenomenology, phenomenological 68, $71,73,75-6,81,162,165,214$, $225,230,231$, also see content, phenomenological

philosophy [listed are express mentions of these terms, not evident from the Table of Contents or (sub) section headings; also see names of representative figures. $-E d$.]; - analytical 13, 18-19, 116, 243, 261, 268; - - ancient 229,$236 ;-1-$ mediaeval $31,77,78,160-1,163,221$; - modern (17th-18th C.) 38, 41, 209, 226, 296; phenomenological $68,162,165$, $214,225,230,231$; —, postmodern 226 ; — 243 also see pragmatism; Scottish 231-2, 233

phlogiston 73, 145-6

physicalism 202, 205, 208, 213, 287, 288, 299n2, also see mind and matter; - , reductive 202, 205, 208, 213, 215n2, 287, 288, 299n2

Planck, Max 144

Plato $15,18,27-8,47,49,51,53$, $54,58-9,60,151,152,227$, 230, 232, 234, 236, 237, 294, $300 \mathrm{n} 7$

pluralism, conceptual 160, 162, 243-9, cf. 209,$210 ;-$, pragmatic 243-9

Poe, Edgar Allan 116-22, 227

Popper, Karl 143, 144, 160, 163, 165 posit 93-6, 99, 101, 103-5, 110-1, 269 possible beings (objects) 18-20, 70, 73, $79,80,84,88,140,142,187$, cf. 166,$183 ;-$ experience(s) 245, 270-1, 273; — worlds 15-20, 108, 117-22, 125-6, 128; also see logic, possible worlds

practical realism see realism, practical pragmatic maxim (method for clarifying ideas) $258,268-9$, 275-6; - realism see realism, pragmatic; — pluralism see pluralism, pragmatic

pragmaticism 221, 254

pragmatics (of language, vs. syntax, semantics) $188,194-5$

pragmatism, pragmatist [listed are express occurrences not evident from the Table of Contents or (sub)section headings; also see names of representative figures. $-E d$.] 159, 160, 168-9; - , classical 164, 251-63, $267,272,276$; - - neo- 200, 
210, 212, 215n2; - , new

284-6, 297-8, 299n4; —

transcendental 161, 251-77

predicate(s) 16, 18, 49, 55-6, 96-101

passim, 109, 181

predication $13,51-2,55,107$,

109, 160, 173, 180-1, 184,

196n9, 248; — , as cognitive

achievement 181-3, 248;

—_, of agency 290ff., also

see ascription of propositional attitude

presentism 165-6, also see actualism, history, past

Price, Huw 200, 202-5, 209-11, 214-15

primatology see biology

Principle of Bivalence see bivalence, Principle of

propositio in re 55

propositio realis 56

propositional attitude see ascription of propositional attitude

Protagoras 27-8

psychology 59, 84, 86, 88, 97, 118-19, 122, 128-32, 209, 210, 237,

275 , also see ascription of propositional attitude

Putnam, Hilary 57, 139-40, 143, 147,

150, 152, 154, 161-4, 167,

169, 196n11, 200, 216n6, 223,

254, 255, 257, 263, 265, 271,

278nn16-17

Puzo, Mario 119, 122

quantification, quantifier (logic) see logic, quantificational

quiddity 50, 53-4, 72, 75, also see essence, re

Quine, W.V.O. 14, 15, 93-113, 129, 152, 155, 163, 165, 196n9, 215n2, 283, 286-8, 296, 298, 299n2

quotation 107,295 , also see truth, disquotational account

radiation, radioactivity 148

Ramberg, Bjørn 209, 284-94, 296, 297-9

Ramsey sentence 203-4, 216n9

re, res 47, 67, 70, 79, 80, also see essence, quiddity

real, reality, $v s$. existence 13-20; reality, formal $v s$. objective 67-89 realism also see actualism; independence, of mind; logic, quantificational; mathematics; object; causal 148-9, 164-9, 174-95;

- common sense 42,47 , 82, 93, 95, 97, 101, 104, 140, $185,187,191,192,206,231-4$, 257 ; — conceptual 47-8, 58-9; — 21, 33-42, 67, 164; — Emersonian 224, 227-32, 234-7; — , entity $v s$. theory 146 ; - ethico-ontological 221-37; —_ external world see independence; —_ formal 51-2; — immanent 47; - , indirect (perceptual, representational) 21,67 ; inductive argument for 143 ; $\longrightarrow$, intensional 48,58 ; internal 159, 161, 162, 169; —, metaphysical 94, 95, 96-7, 105, 139-40, 146, 161, 200-2, 206, 207; —, mereological 58, 59; minimal 265, 275-6, 279n37; - , minimal scientific 145 , $147 ;$ _ ontological see independence; - , Platonic $51 ;-$, practical (Vihalemm) 274-6; - pragmatic 221-99 passim; _ , propositional, 46, 54-6, 60, also see propositio in re, realis; unregenerate 93, 94, 100, 103-5; — , with lower-case ' $r$ ' 57 ; - with capital ' $\mathrm{R}$ ' 57 ; — , scholastic 47, 61n5, 223, 236, 254, 255, 266; - scientific see scientific realism; —_, semantic 150-5, 160, 169-70; - , about universals 46-54, 58-60, also see generals; realism, scholastic

reality, actual 14-20 also see actualism, presentism; - existence, actuality 17-20; _ , formal vs. objective 77-89; Inaccessibility of Reality Argument 164; — see object, possible; re; 'sideways-on' view of, 214; Reality Principle 117, 118, 120-2, 126 
reason 56-7, 224-5, 233, 264 also see mind; _ - vs. understanding 232; reasons, space of $285,297-9$ reciprocal containment (of science and epistemology) 100, 111, cf. 279n 38

reductive empiricism see empiricism, reductive

reference also see content, intensional; logic, quantificational; semantics; reference, reference relation(s), denoting $14,17,18$, 70-2, 75, 84, 93, 95, 97-104, $130,132,142,145,148$, $150,161,162,167-8,173-4$, 189-95, 210, 247, 252, 258; - , naturalistic theory of 202-7, 288-99; __ Thesis of Singular Cognitive, 180-8; to scientific non-observables 20 , 95, 100, 143, 145-8, 155, 167, 189, 261-2, cf. 177

reflexive intentions see intentions, reflexive

Reid, Thomas 232 reification, reify 93 relative, $v s$. absolute or non-relational $14,16,39-40,163,246-9$, 274-5, also see independence; mind-independent

relativism 144, 159, 160, 243, 246, $249,251-2,257,262,263$ relativity, conceptual 263 , also see conceptual scheme; perceptual 142

representationalism 21, 23, 32-4, 47, $67,76,88,131,200-2,205-7$, 210-11, 214, 226, 269, 272-3, 283, 287, also see content, reference, truth

Resnais, Alain 128

Rip Van Winkle (fictional character) 123

Röntgen, Wilhelm 148

Rorty, Richard 161, 200, 208, 209, $212,226,255,256,263$, 283-92, 295-9

Rule 4 (Newton), see scientific $\operatorname{method}(\mathrm{s})$

Russell, Bertrand 13-19, 73, 169, 181

$S$-worlds see storyworlds

Scheherazade (fictional character) 116, $118-21$

Schelling, F.W.J. 222, 223 scheme $v s$. content see conceptual scheme

Schlick, Moritz 152, 153, 195n3 science also see biology, paleontology, Theory of Mind (ToM); cosmology 15; General Theory of Relativity 174, 179; natural $57,58-9,86-8,93-7$, 100-6, 110-11, 116-19, 139-215 passim, 221-8, 233, $235,246,252,259-62,287-9$; - , mature $146-7$; — $93,273,275$

scientia 18, 46, 50, 59-60, 183, 186, 188

scientific, community $237,255-6$; explanation see explanation, scientific; - method(s) 147, 149, 164, 173-9, 185-7, 193, 221, 223, 226, also see abduction; Rule 4 (Newton) 173-5, 179-80, 185-8, 191, 195n7; - observation, theoryladen $147, c f .274 ;$ — realism 47-8, 139-215 passim; realism, Convergent 146; realism, Critical 159-60, 274; — realism, minimal 145 ; realism, Newton's 173-93; realism, Standard 145-6; realism, Strong 146 ; — terms, observational $v s$. theoretical 99, 144, 149, also see empiricism, Constructive; observation; observation, sentence; theory, well-established 146 Scotus, John Duns 22-3, 39-41, 47, $51-2,54,59-60,77,163,166$ Searle, John 81, 132, 202, 205-7 Sellars, Wilfrid 143, 144, 152, 160, 164, 261, 284, 285, 286, 297 semantic(s) 46-59 passim, 139-40, 159, 212, 252, also see bivalence; truth; - content see content, semantic; - externalism 272; — minimalism 210, 212; paradox of material implication (Brandom) 191; _ postulates 183 ; — vs. pragmatics, syntax (Morris) 194-5; realism $150-5,160,162-4$, 203-5, 210, 212, 252, 292, also see representationalism; truth; - - cognitive 173, 180-8; - Frege-Russell 
17-20; -, scientific 212;

- truth-conditional 151,

153-4, 296, also see truth;

—

anti-realism see anti-realism,

semantic; — realism see

realism, semantic; —- possible

worlds see logic, possible worlds semiotics 161, 194-5, 252, 254

sentence, observation, see observation,

sentence; - occasion, see

occasion sentence; also see

content, of sentence; content, of statement

Seventh Voyage, The 118, 127-9

shared cultural background 129 ,

131-2, also see Mutual Shared

Belief

Sheikh Yerbouti 118, 121, 122

simplex apprehensio 82-3

Sinbad (fictional character) 116, 118

Six Walks in the Fictional Woods 121

skepticism 140-1, 145, 149, 159, 160,

170, 183, 184, 193, 202, 203,

223, 252, 261, 262, 270-1

Slater, Michael 19, 256-9

Smart, J.J.C. 144, 147, 167

Smith, Adam 232

Smith, George 177

social constructivism $144,148,159$,

164, 168, 252, 255-6, cf. 93,

$161,261,265$

Socrates 18, 25, 49, 51-4, 58

solipsism 159, 168

space of nature see nature, space of space of reasons see reasons, space of

"Sphinx, The" (poem, Emerson) 222, 231

spontaneity, vs. receptivity 284, 287

Standard Scientific Realism see scientific realism, Standard states of affairs 19, 48, 58, 132, 160, 184, 252, 275; also see fact(s)

Stewart, Dugald 232

Stich, Steven 203, 205

storyworlds ( $S$-worlds) 117-19

Stout, G. F. 141, 284

Strawson, Peter 142, 267

Strong Scientific Realism see scientific realism, Strong

structure(s) 13, 16, 58-9, 85, 99, 109, 130-2, 139, 147, 151, 160-5, $179,180,189,207,214-15$, $247-8,251,255-6,264,272-3$

Suarez, Francesco 60n3, 68, 74, 77, 82-3 success argument see miracle argument system of beliefs see belief system

Tarski, Alfred 160, 164, 168

Terminator, The 128

theory, scientific, see science

Theory of Mind (ToM) 129-31

theory-ladenness of observation see observation, theory-laden

things-in-themselves (Ding an sich) 144, 160, 161-2, 211, 214, 255, 259, 265, 267-8, 273, 297

Thompson, E. 214

"Thousand-and-Second Tale of

Scheherazade, The" (Poe) 116

Tichy, Ion (fictional character) 127-9

Time Machine 128

"Tlön, Uqbar, Orbis Tertius" (Borges) 119

Tomasello, Michael 129-30

Tractatus logico-philosophicus

(Wittgenstein) 14, 15, 278n17

Transcendental Idealism (Kant) see idealism, transcendental

transcendental pragmatism see pragmatism, transcendental

Transcendentalism, New England 222, 264

translation, indeterminacy of $216 \mathrm{n} 6$, 286-90

Travis, Charles 184

truth $23,47,51,188-9,211,213$, 223, 225, 247, 288, 295-99; - absolute 231, 248, 257, cf. 253, also see God's-eye view; - - aim of inquiry 144, 226, 229, 231, 235, 252-4; - , approximate see truthlike(ness); —_, coherence account of 254 ; - conditions 153-4, 164, 286, 292-9; - , consensus account of 254 ; correspondence $56,74,82,139$, 144, 146, 152, 159-60, 206, 207, 216n13, 252, 254, 256-7, 274, 296-7; - - criteria $v s$. analysis (or nature of) 258; - deflationism about 203, 206, 210; - - disquotational account of 145, 297; epistemic account of 169, 258, also see justification, warranted assertability; - evaluability 182, 184, 186, 214, cf. 162;

—, fictional 88-9, 115-33; 
truth in fiction see truth, fictional; - maker(s) 168, 208, 217n17; —-, objective 164, also see independence, of mind; realism; - ontological 82, 232-3; account(s) of 164, 251, 258, 297-9; — , propositional 55; - Tarskian account of 160 , 164,168 ; - verificationtranscendent 150-2, 163-4, 212, 286, 292, 295; verificationist account of 151 , $154,112 \mathrm{n} 10 ;-$, as warranted assertability 169

truthlike(ness) $160,162,167,262, c f$. $147,149,231,235$

Turn of the Screw 124

Twardowski, Kasimiercz 73-4, 79, 83-4

Ugly Dave (fictional character) 124-5 underdetermination of theory by observation 149, 174, 287-8

understanding, epistemic conception of 153-4, 170, cf. 292-4; (Verstand), vs. reason (Vernunft) 165,232

use $v s$. mention 107

van Fraassen, Bastian C. 167, 173, 179, $185,188-95$

verification-transcendent truthconditions see truth conditions, verification-transcendent
Vienna Circle, the, 152; also see Logical Positivism

Vihalemm, Rein 251, 274-6

Walsh, Peter (fictional character) 115

Walton, Kendall 120-1

warranted assertability, see justification, warranted assertability; truth, as warranted assertability

Watson, John H. (fictional character) 127

'we' intentionality see attention, joint; intentionality

Wee, Cecilia 68, 81-2

Welles, Orson 118

Wells, H. G. (Herbert George) 128

Wells, Norman 68, 78, 82

Westphal, Kenneth R. 251, 266, 270-6, $278 \mathrm{n} 23$

Williams, D. C. 143

Wilson, Catherine 67-8

Wilson, C.T.R. 167

Wilson, Margaret 79-82

Wittgenstein, Ludwig 14, 15, 129, 143, 200, 234, 270-3, 276

Wolff, Michael 183

Woolgar, Steven 144, 164 worlds, possible see logic, possible world; object, possible

worlds, story ( $S$-worlds) see storyworlds

Wright, Crispin 152, 154

Wyclif, John 49-50, 54-6, 59-60

Zappa, Frank 118, 121, 122 


\section{Routledge Studies in Contemporary Philosophy}

For a full list of titles in this series, please visit www.routledge.com

24 Philosophical Delusion and its Therapy

Outline of a Philosophical

Revolution

Eugen Fischer

25 Epistemology and the Regress Problem

Scott F. Aikin

26 Civil Society in Liberal

Democracy

Mark Jensen

27 The Politics of Logic

Badiou, Wittgenstein, and the

Consequences of Formalism

Paul M. Livingston

28 Pluralism and Liberal Politics Robert B. Talisse

29 Kant and Education Interpretations and Commentary Edited by Klas Roth and Chris W. Surprenant

30 Feminism, Psychoanalysis, and Maternal Subjectivity Alison Stone

31 Civility in Politics and Education Edited by Deborah S. Mower, Wade L. Robison
32 Philosophical Inquiry into Pregnancy, Childbirth, and Mothering

Maternal Subjects

Edited by Sheila Lintott and

Maureen Sander-Staudt

33 Authenticity as an Ethical Ideal Somogy Varga

34 The Philosophy of Curiosity Ilhan Inan

35 Self-Realization and Justice A Liberal-Perfectionist Defense of the Right to Freedom from Employment Julia Maskivker

36 Narrative Identity, Autonomy, and Mortality

From Frankfurt and MacIntyre to Kierkegaard

John J. Davenport

37 Contemporary Feminist Pragmatism Edited by Maurice Hamington and Celia Bardwell-Jones

38 Morality, Self Knowledge, and Human Suffering An Essay on The Loss of Confidence in the World Josep Corbi 
39 Contrastivism in Philosophy

Edited by Martijn Blaauw

40 Aesthetics After Metaphysics

From Mimesis to Metaphor

Miguel de Beistegui

41 Foundations of Freedom

Welfare-Based Arguments against

Paternalism

Simon R. Clarke

42 Pittsburgh School of Philosophy

Sellars, McDowell, Brandom

Chauncey Maher

43 Reference and Structure in the Philosophy of Language

A Defense of the Russellian

Orthodoxy

Arthur Sullivan

44 Civic Virtue and the Sovereignty of Evil

Derek Edyvane

45 Philosophy of Language and Webs of Information

Heimir Geirsson

46 Disagreement and Skepticism

Edited by Diego E. Machuca

47 Philosophy in Schools

An Introduction for Philosophers

and Teachers

Edited by Sara Goering,

Nicholas J. Shudak, and

Thomas E. Wartenberg

48 A Philosophy of Material

\section{Culture}

Action, Function, and Mind

Beth Preston

49 A Philosophy of the Screenplay Ted Nannicelli
50 Race, Philosophy, and Film

Edited by Mary K. BloodsworthLugo and Dan Flory

51 Knowledge, Virtue, and Action Essays on Putting Epistemic Virtues to Work Edited by Tim Henning and David P. Schweikard

52 The Ontology of Psychology Questioning Foundations in the Philosophy of Mind Linda A.W. Brakel

53 Pragmatism, Law, and Language

Edited by Graham Hubbs and Douglas Lind

54 Contemporary Dualism

A Defense

Edited by Andrea Lavazza and

Howard M. Robinson

55 Reframing the Intercultural Dialogue on Human Rights

A Philosophical Approach Jeffrey Flynn

56 How History Matters to Philosophy

Reconsidering Philosophy's Past

After Positivism

Robert C. Scharff

57 The Affordable Care Act

Decision

Philosophical and Legal

Implications

Edited by Fritz Allhoff and

Mark Hall

58 Realism, Science, and

Pragmatism

Edited by Kenneth R. Westphal 